\title{
EKSPRESI ANTI-HELICOBACTER PYLORI PADA GASTRITIS KRONIS, LESI PRAKANKER, DAN KARSINOMA GASTER
}

\author{
Lina Damayanti, Bambang Endro Putranto,Udadi Sadhana \\ Bagian Patologi Anatomi Fakultas Kedokteran Universitas Diponegoro/ RSUP Dr. Kariadi, J1. Dr.Sutomo 16-18 Semarang \\ Korespondensi: Lina Damayanti \\ email: lina.pa75@yahoo.com
}

\begin{abstract}
ABSTRAK
Pevalensi infeksi Helicobacter pyloridi Indonesia adalah 36-46.1\%. Di Jakarta dan Surabaya infeksi H Pylori mencapai 85,7\%-93,9\%. Infeksi H pylori diduga merupakan penyebab utama ulkus peptikum (peptic ulcer), gastritis kronis, karsinoma lambung dan gastric lymphoma.Studi epidemiologis menunjukkan lebih dari $80 \%$ kasus karsinoma lambung dikaitkan dengan adanya infeksi H Pylori.Penelitian ini bertujuan untuk mengetahui ekspresi kuman H pylori pada lesi gastritis kronik, lesi prakanker, dan karsinoma lambung. Penelitian inimerupakan penelitian deskriptif observasional dengan desain cross sectional. Tiga puluh blok paraffin yang didiagnosis sebagai gastritis kronis, lesi prakanker dan karsinoma lambung pada tahun 2013 di RS Dokter Kariadi dilakukan pulasan hematoksilin, giemsa dan immunohistokimia anti-helicobacter pylori. Data yang diperoleh dilakukan analisis deskriptif. Tiga puluh sampel terdiri dari 13 gastritis kronis, 11 lesi prakanker, dan 6 carcinoma. Gastritis kronis dapat terjadi pada semua umur, sedangkan carcinoma gaster terbanyak terjadi pada laki-laki usia lebih dari 40 tahun. Ekspresi Helicobacter pylori pada gastritis kronis 84,6\%, lesi prakanker 54,5\% dan carcinoma gaster $83,3 \%$. Terjadi false positive $23,3 \%$ dan false negative $20 \%$ dengan menggunakan pengecatan giemsa. Ekspresi Helicobacter pylori dapat ditemukan pada gastritis kronis, lesi prakanker maupun carcinoma gaster.
\end{abstract}

Kata Kunci: Gastritis kronis, karsinoma gaster, Helicobacter pylori.

\section{ABSTRACT}

Prevalence of Helicobacter pylori infection in Indonesia was 36-46\%. In Jakarta and Surabaya, the prevalence were $85,7 \%-93,9 \%$. Helicobacter pylori infection play role in pathogenesis of pectic ulcers, chronic gastritis, carcinoma of gaster and gastric lymphoma. Epidemiologic study showed $80 \%$ of carcinoma of gaster related with $H$ pylori infection.This study analyzed expression of anti-Helicobacter pylori in chronic gastritis, precancer lesion, and carcinoma of gaster. This study was a observational descriptive study with case control design. Thirty (30) samples from paraffin bloc that were diagnosed with chronic gastritis, precancer lesion, and carcinoma of gaster at Dokter Kariadi hospital in 2013 was stained by hematoxylin eosin, giemsa and immunohistochemistry of anti-helicobacter pylori. Data was analyzed by descriptive analysis. Thirty (30) samples were diagnosed as gastritis chronis 13 (43,3\%), pra cancer lesion(36.6\%), and carcinoma(20.1\%). Chronic gastritis can be occurred at all age and no distinct difference on sex, while gastric carcinoma predominant in male older than 40 years. Expresion of Helicobacter pylori on chronic gastritis was $84.6 \%$, precancer lesion was $54.5 \%$, and gastric carcinoma was $83.3 \%$. The Giemsa stain gave $23.3 \%$ false positive and $20 \%$ false negative. Helicobacter pylori expression can be showed in chronic gastritis, precancer lesion, and gastric carcinoma.

Keywords: Chronic gastritis, gastric carcinoma, Helicobacter pylori

\section{PENDAHULUAN}

Infeksi Helicobacter pylori merupakan penyebab utama ulkus peptikum (peptic ulcer), gastritis kronis, karsinoma lambung dan gastric lymphoma.H.pyloriini masih merupakan masalah besar di Indonesia karena angka insidennya yang tinggi dan peranan infeksi H.pylori dengan timbulnya gastritis kronis dan karsinoma gaster diduga sangat besar. Prevalensi infeksi H.pylori di Indonesia adalah $36-46,1 \%$ dengan $5,3-15,4 \%$ diantaranya ditemukan pada pasien berusia di bawah 5 tahun, namun data penelitian di Jakarta dan Surabaya menunjukkan prevalensi H.pylori pada penderita ulkus masing-masing sebesar $100 \%$ 
dan $85,7-93,9 \%$. Prevalensi gastritis kronis yang disebabkan oleh infeksi Hpyloriyang dilakukan pemeriksaan histopatologi di RS Ulin mencapai 70\%. Tahun 2005 dilakukan penelitian di Semarang dengan melakukan uji urease pada kelompok masyarakat dan menunjukkan angka prevalensiH pylori yang rendah $2 \%$ (Oktaviyanti\&Rosida, 2013;Syaifudin, 2008; Tokudome, 2005).

Gastritis kronis secara epidemiologi dan biologi dihubungkan dengan terjadinya kanker gaster. Beberapa penelitian juga menyebutkan $H$ pylori di duga mempunyai peran dalam patogenesis gastritis kronis dan kanker gaster. Namun demikian faktor carcinogenesis ini dipengaruhi oleh berbagai faktor meliputi lingkungan, strain bakteri dan respon imun tubuh (Ahmed, 2014; Parsonett et al, 1991) Studi epidemiologis saat ini, juga menunjukkan lebih dari $80 \%$ kasus karsinoma lambung dikaitkan dengan adanya infeksi $H$ pylori (Eugenia, 2011; Miehlke et al, 1997; Nagini, 2012). Penelitian di negara-negara maju menunjukkan pula hubungan infeksi bakteri ini dengan karsinoma lambung, namun masih menjadi kontroversi di Jepang (Maeda et al, 2000).Fukuda et al. melaporkan bahwa tidak ada hubungan antara H.pylori dan perkembangan karsinoma lambung (rasio odds 1,04), sedangkan Kikuchi et al. melaporkan terdapat hubungan antara keduanya (rasio odds 13,3). Maeda et al juga menyebutkan bahwa karsinoma lambung disebabkan oleh H.pylori sebagai akibat atrofi maupun metaplasia yang berlangsung lama(Komoto et al, 1998; Maedaet al, 2000; Semino-Moraet al, 2003; Zhanget al, 2005; ).

Penelitian ekspresi anti $H$. pylori pada karsinoma lambung di Indonesia belum pernah dilakukan, epidemiologi penyebab karsinoma lambung di Indonesia juga belum pernah diteliti, untuk itu penelitian ini bertujuan untuk mengetahui ekspresi kuman H.pylori pada lesi gastritis kronik, lesi prekanker dan karsinoma lambung dan membandingkan hasil pengecatan giemsa dan immunohistokimia anti-H pylori.

\section{METODE}

Penelitian ini adalah penelitian observational dengan rancangan cross sectional. Sampel penelitian sebanyak 30 blok paraffin dari gaster yang didiagnosis sebagai gastritis kronik,atrofi, metaplasia intestinal, dysplasia, dan carcinoma gaster baik yang tipe diffuse atau intestinal dilakukan pulasan hematoksilin eosin, giemsa, dan immunohistokimia anti-helicobacter pylori.

Data-data primeryangdikumpulkanmeliputi jenis kelamin, umur, jenis lesi berupa gastritis kronik, jenis inflamasinya, atrofi, metaplasia, dan displasia.Pemeriksaan mikroskopis dilakukan oleh 2 pemeriksa.

\section{HASIL DAN PEMBAHASAN}

Pada penelitian ini didapatkan jumlah sampel sebanyak 30 buah yang diambil selama periode tahun 2013.Dari 30 sampel, 24 merupakan kasus gastritis kronis dan lesi prakanker dan 6 sampel berupa lesi kanker yaitu adenocarcinoma. Data yang kami ambil meliputi jenis kelamin, usia, jenis lesi, jenis inflamasi kronis aktif dan non aktif, atrofi, metaplasia intestinal, displasia, dan pengecatan hematoksilin eosin, giemsa dan immunohistokimia anti-H pylori.

Berdasarkan jenis kelamin lesi gastritis terbanyak terjadi pada perempuan 7 orang $(53,8 \%)$, sedangkan lesi prakanker terbanyak pada laki-laki yaitu 8 orang $(72,7 \%)$. Adenocarcinoma terjadi terbanyak pada laki-laki sebanyak 5 orang $(83,3 \%$ ). Menurut kelompok umur, lesi gastritis kronik terjadi terbanyak pada usia 41-50 tahun yaitu 5 orang $(38,5 \%)$, sedangkan lesi prakanker terjadi terbanyak pada kelompok umur lebih dari 60 tahun (54,5\%). Untuk carcinoma, usia terbanyak terjadi pada kelompok umur 51-60 tahun( $50 \%$ ). Ekspresi $H$ pyloriterdapat pada $83,3 \%$ sampel gastritis kronis, 54,5\% lesi prakanker, dan 83,3\% karsinoma gaster. Terdapat hasil false positive sebesar 23,3\% dan false negative 20\% dengan pengecatan giemsa.

Sebagai bakteri patogen, Hpylori bisa hidup dilingkungan asam, untuk kemudian mempenetrasi mukosa gaster, dan akhirnya mengkolonisasi mukosa gaster. Bakteri ini mempunyai beberapa faktor yang penting meliputi urease (Ure A-1), endotoxin lipopolisaccharide(LPS), flagellin ( fla A, fla B), adhesion (hpa,bab A1, hopZ, alp A, alp B) dan protein yang mengaktifkan netrofil (nap, neutrofil activating protein). Semua faktor diatas ditemukan pada semua strain H Pylori, sedangkan 
faktor-faktor seperti antigen cagA, molekul PAI, vacA/s1, ice-A1 tidak ditemukan pada semua strain H Pylori(Paz-Bouzalet al, 1991).

Gastritis karena $H$ pylori lebih banyak terjadi didaerah antrum daripada corpus. Resistennya corpus terhadap kolonisasi $H$ pylori dan inflamasi disebabkan karena konsentrasi asam lambung yang tinggi di corpus.H pylori memiliki mekanisme yang menyebabkan bakteri ini bisa bertahan pada kondisi lingkungan lambung yang asam. Pada $\mathrm{pH}$ yang berkisar antara 3.5 sampai 5.0 dengan adanya urea, bakteri ini dapat menyeimbangkan proton motive force $(P M F)$ di membran periplasmiknya, memastikan adanya suplai energi yang berkesinambungan melalui sintesis ATP. Urea akan dirubah oleh urease di dalam sitoplasma menghasilkan ammonia yang menetralkan ion hidrogen yang berlebihan untuk mempertahankan $\mathrm{pH} 6.2$ di celah periplasmik dan mempertahankan PMF. Meskipun begitu, jika konsentrasi asam sangat tinggi, mekanisme protektif gagal untuk menjaga peningkatan kadar ion hidrogen, sehingga terjadi penurunan sintesis ATP, dan bakteri akan mati, atau kehilangan faktor virulensinya. Corpus menjadi daerah yang kurang cocok untuk bakteri ini, sehingga densitas kolonisasi dan inflamasi terfokus di daerah antrum.. Diatas $\mathrm{pH} 8$ sel tidak dapat berfungsi,sehingga dalam kondisi gaster yang achlorhydric, H pylori akan hancur dengan sendirinya dan infeksi akan secara spontan tereliminasi (Dixon, 2001).

Secara histologi, respon tubuh terhadap infeksi $H$ pylori ditandai dengan infiltrasi sel plasma, limfosit, netrofil dan monosit di dalam mukosa gaster. Respon inflamasi imun tubuh mempunyai peran penting dalam menginduksi kerusakan mukosa gaster oleh karena infeksi $H$ pylori.Pada gastritis akut yang disebabkan infeksi $H$ pylori, netrofil memenuhi komponen inflamasi awal sebagai respon terhadap patogen yang masuk.Netrofil yang teraktivasi mempunyai banyak komponen yang mungkin berperan dalam kerusakan jaringan.Kemotaksis netrofil dan aktivasinya dapat dipicu langsung dari produk $H$ pylori dan dapat juga secara tidak langsung melalui kaskade sitokin proinflamasi (Charalabopouloset al, 2003).

H pylori telah ditetapkan oleh WHO/IARC sebagai carcinogen untuk terjadinya kanker gaster. Mekanisme infeksiH pylori sampai berkembang menjadi kanker gaster adalah sebagai berikut: infeksi $H$ pylori yang persisten menyebabkan gastritis yang persisten secara histologi, dimana eksfoliasi dan repair mukosa terjadi sangat cepat. Dengan pengaruh genetik dan faktor lingkungan berkembang menjadi atrofi mukosa, yang akhirnya berkembang menjadi atrofi mukosa gaster, dilanjutkan perubahan metaplasia intestinal menjadi dysplasia (Suzukiet al, 2005). Pada penelitian ini terdapat enam sampel dengan karsinoma gaster, 5 kasus terjadi pada laki-laki dengan usia lebih 40 tahun, dan satu kasus pada perempuan. Ekspresi H pyloriterdapat pada 5 buah sampel $(83,3 \%)$ dari 6 buah sampel karsinoma.

H pylorimempunyai efek carcinogen secara langsung melalui faktor virulensinya dan secara tidak langsung melalui respon inflamasi dari sel host. Faktor-faktor virulenH pyloriseperti urease, phofolipase A, enzim proteolitik, yang semuanya terdapat pada seluruh strain $H$ pylori dan cagA ( terdapat pada $60-70 \%$ ) dan vacA ( pada $60-65 \%$ ) sangat berperan dalam mekanisme terjadinya keganasan pada gaster.Faktor seperti cagA, cagE dan vacA mempengaruhi apoptosis sel epitel gaster. CagA mempunyai peran dalam resiko terjadinya kanker gaster pada populasi barat, sedang di Asia, faktor yang berpengaruh dalam lesi sel epitel adalah vacA s1 dan vacA $\mathrm{m} 1$ (Charalabopoulos et al, 2003; Dixon, 2001;Paz-Bouzalet al, 1991).H pylori melalui cagA mengaktifkan reseptor faktor pertumbuhan, meningkatkan proliferasi, menghambat apoptosis, meningkatkan invasi dan angiogenesis (Nagini, 2012).

Respon inflamasi menjadi faktor yang secara tidak langsungberperan dalam terjadinya kanker. Mukosa gaster yang terinfeksi $H$ pylori menunjukkan peningkatan nyata sitokin seperti IL-1, IL-1 $\beta$, Il-2, IL-8,TNF $\alpha$. Sitokin dan kemokin tidak hanya bekerja sebagai mediator inflamasi, tetapi juga berpengaruh terhadap sekresi asam lambung dan kerusakan mukosa gaster. Ekspresi sitokin secara sekunder juga mengaktivasi faktor transkripsi NF-kB, dimana mengaktivasi sel-sel epitel melalui translokasi gen cagA (Charalabopouloset al 2003 Suzukiet al, 2005).

Reaksi inflamasi, terutama yang kronis, dapat menjadi sumber signifikan dari kerusakan oksidatif. Leukosit seperti makrofag dan neutrofil aktif akan melepaskan sejumlah ROS, termasuk $\mathrm{H}_{2} \mathrm{O}_{2}$, oksida nitrat $\left(\mathrm{NO} \bullet\right.$ ), super oksida $\left(\mathrm{O}_{2} \cdot{ }_{2}\right)$, hidroksil ( $\mathrm{OH} \bullet$ ), dan hipoklorit (hocl), yang dapat merusak sel DNA di dekatnya. Diantara 
semuanya, superokside, hidroksi peroksida dan radikal hidroksil telah banyak diteliti berhubungan dengan pathogenesis kanker.. Radikal hidroksil diketahui bereaksi dengan seluruh komponen molekul DNA yaitu purin dan pirimidin serta deoxyribose (Micuet al, 2010; Yuanet al, 2004)

Terbentuknya stress oksidatif dikenali sebagai faktor virulensi pada individu yang terinfeksi $H$ pylori. Infeksi $H$ pylori menginduksi produksi oksigen reaktif dan nitrogen spesies dan menekan mekanisme antioksidan faktor host menyebabkan kerusakan DNA. Walaupun H pylori tidak secara langsung bersifat mutagen, namun diduga pembentukan zat yang bersifar mutagen melalui mediator inflamasi atau lewat gangguan pada proses repair. Kim et al membuktikan bahwa infeksi H Pylori meningkatkan proses karsinogen pada gaster dengan cara meningkatkan kerusakan DNA endogen dengan cara menurunkan aktifitas repair dan menginduksi mutasi pada mitokondria dan inti DNA. Proses metilasi DNA yang diinduksi infeksi $H$ Pylori merupakan faktor resiko yang signifikan untuk kanker gaster (Miehlke et al, 1997; Noda \& Wakasugi, 200; Valko etal, 2004; Yuanet al, 2004).

Di bawah ini adalah gambar mikroskopis dari sampel penelitian

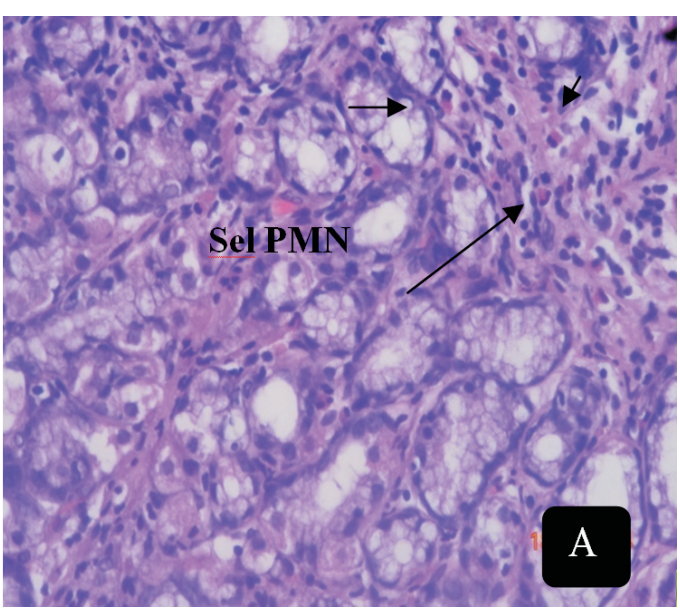

Gastritis kronik aktif

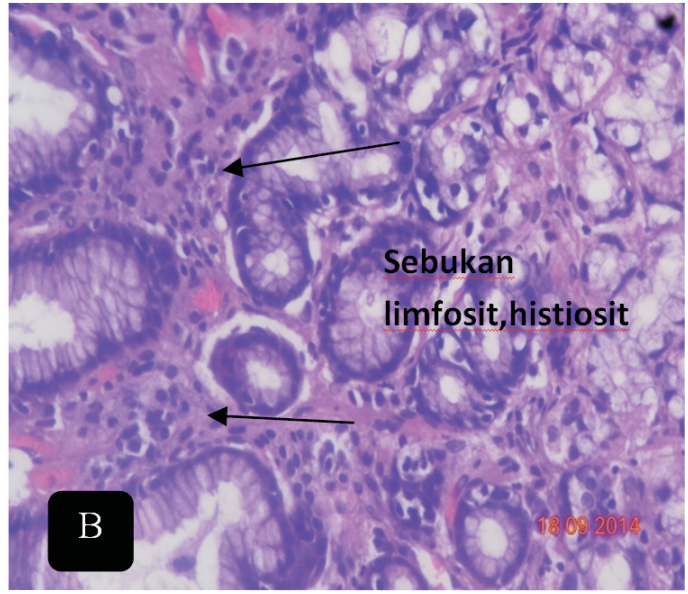

Gastritis kronik non aktif

Gambar 3. A. Dengan pembesaran 400X menunjukkan sebaran sel polimorfonuklear yaitu eosinofil dan netrofil dengan latar belakang sel radang kronis

B. Dengan pembesaran 400X menunjukkan sebaran sel radang limfosit, dan histiosit

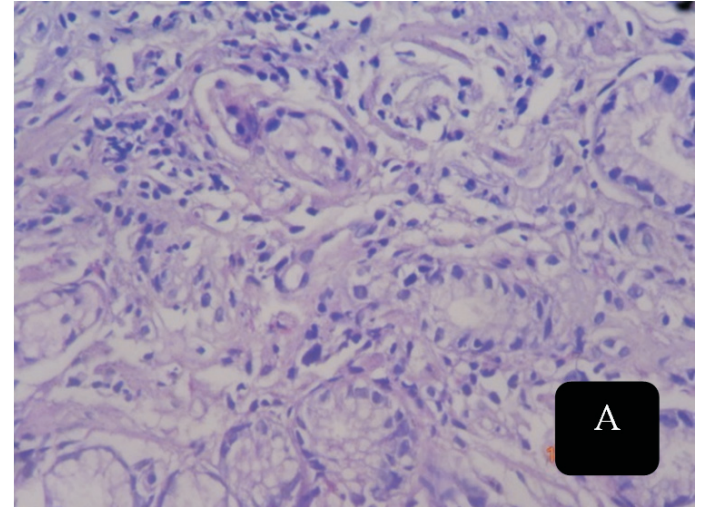

Gastritis atrofik

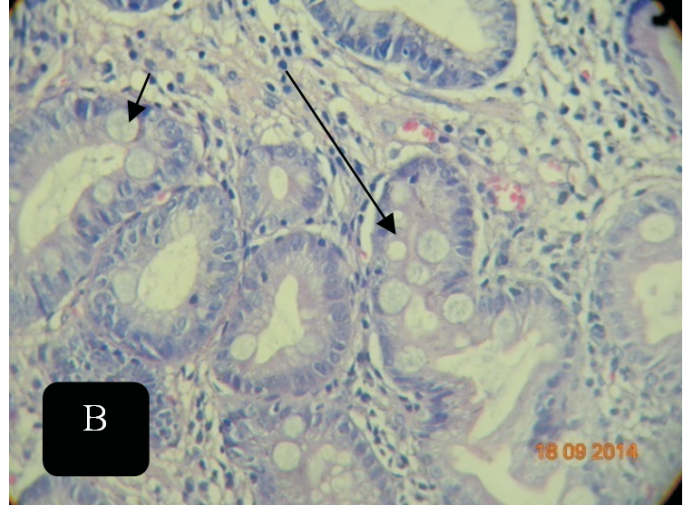

Metaplasia intestinal (+)

Gambar 4. A. Pembesaran 400X menunjukan gastritis atrofi.

B. Pembesaran 400X menunjukkan lesi metaplasia intestinal 


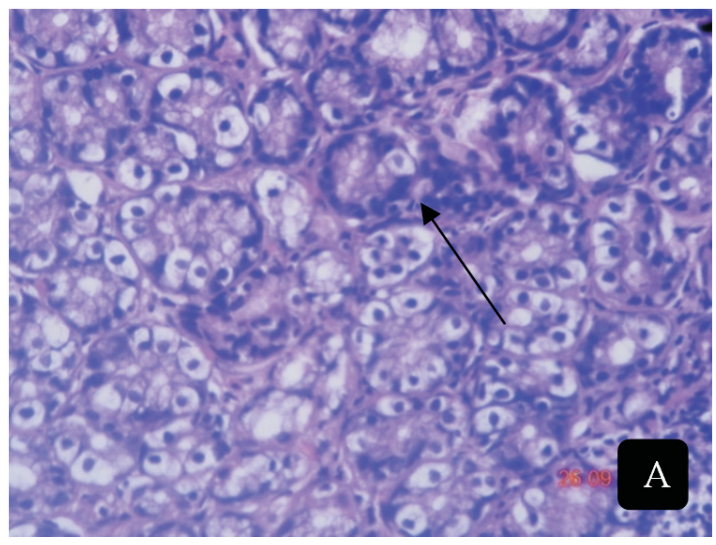

Displasia $(+)$

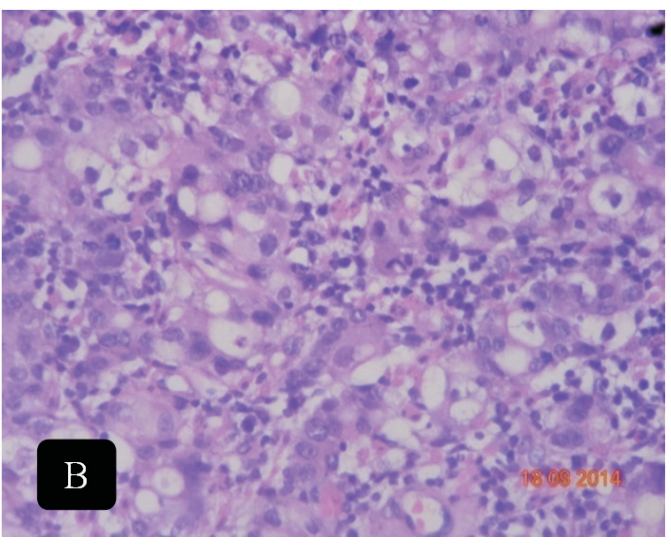

Adenocarcinoma

Gambar 5. A. Pembesaran 400X menunjukan lesi displasia B. Pembesaran 400X menunjukkan carcinoma

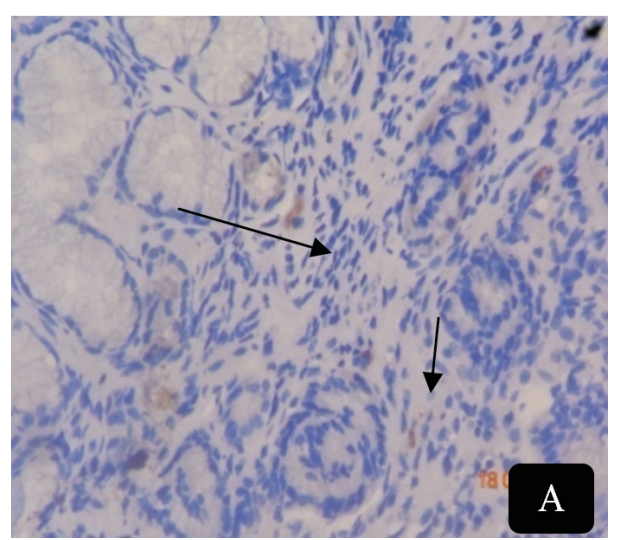

H pylori $(+)$ pada gastritis

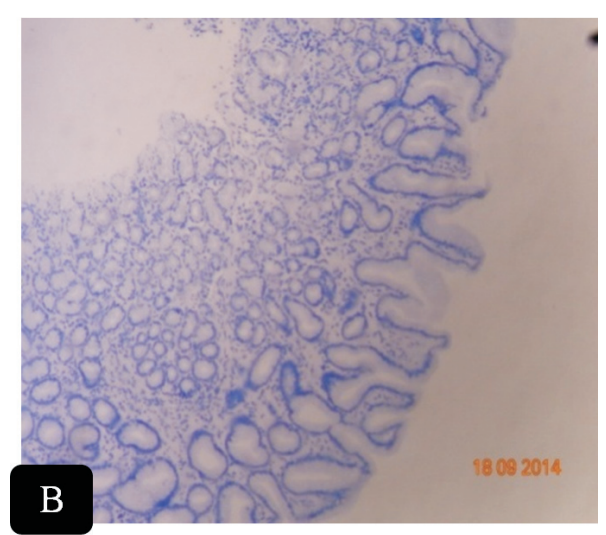

H pylori (-) pada gastritis

Gambar 6. A. Pembesaran 400X menunjukkan pulasan immunohistokimia positif berwarna coklat disertai kuman bentuk coccoid

B. Pembesaran 200X menunjukkan pulasan immunohistokimia negatif

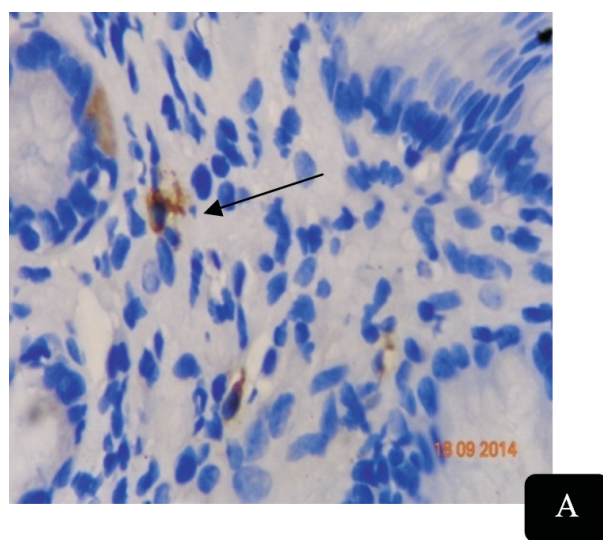

H pylori (+) pada lesi prakanker

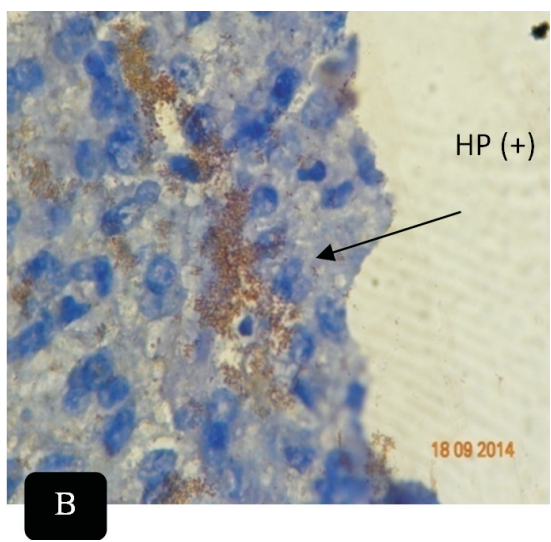

H pylori (+) pada carcinoma

Gambar 7. A. Pembesaran 400. Menunjukkan pulasan immunohistokimia positif pada daerah sekitar crypte B. Pembesaran 400X. Menunjukkan pulasan immunohistokimia positif pada lesi carcinoma disertai bakteri bentuk spiral, dan cocoid 


\section{SIMPULAN}

1. Berdasarkan dasar teori yang menunjukkan bahwa $H$ pylori berperan dalam pathogenesis gastritis kronik, atrofi, metaplasia intestinal, displasia dan meningkatkan resiko terjadinya karsinoma gaster, serta hasil penelitian ini yang menyebutkan ekspresi $H$ pylori dapat ditemukan pada gastritis kronis(84,6\%), lesi prakanker (54,5\%) dan karsinoma gaster( $83,3 \%)$,maka dapat disimpulkan bahwa $H$ pylori dapat berperan dalam pathogenesis terjadinya gastritis kronis dan menjadi faktor resiko terjadinya karsinoma gaster.

2. Pengecatan giemsa memberi hasil false positive $23,3 \%$ dan false negative $20 \%$.

\section{SARAN}

1. Dengan adanya data ekspresi $H$ pylori pada gastritis kronis, lesi prakanker, dan karsinoma gaster peneliti mengusulkan adanya penelitian berkelanjutan dengan bagian gastroenterology untuk lebih menganalisis peran $\mathrm{H}$ pylori pada gastritis kronis, lesi prakanker, dan karsinoma gaster dengan jumlah sampel yang lebih besar dan jangka waktu yang lebih lama.

2. Pengecatan immunohistokimia untuk deteksi H pylori yang lebih akurat.

\section{DAFTAR PUSTAKA}

Ahmed N, Tenguria S, Nandawar N., 2014.Helicobacter pylori- a seasoned pathogen by any other name. Gutpathogen. Available from http:// www.gutpathogens.com/content/1/1/24

Charalabopoulos K, Papalimneou V, Agnantis NJ.2003., Pathogenetic mechanism involved in stomach infection caused by Helicobacter pylori.Hipokratia, 7(4):173-76

Dixon M.F., 2001. Pathology of gastritis and peptic ulceration in Mobley HLT, Mendz GL, Hazell SL,(eds).Helicobacter pylori:Pysiology and genetics.Washington:ASM Press

Eugenia SD. 2011.,Histopathological study and immunohisthochemical studi of gastric carcinoma. Doctoral thesisSummary.

E, Oktaviyanti I.K, Rosida L., 2013.Gambaran derajat infiltrasi sel radang dan infeksi Helicobacter pylori pada biopsi lambung pasien gastritis. Berkala Kedokteran. 9(1):47-551.

Komoto K, Haruma K, Kamada T, Tanaka S, Yoshihara
M, Sumii K, et al., 1998. Helicobacter pylori Infection and gastric neoplasia: Correlation with histological gastritis and tumor histology. Am J Gastroenterol. 93(8):12717.

Maeda S, Yoshida H, Ogura K, Yamaji Y, Ikenoue T, Mitsushima T, et al., 2000. Assessment of gastric carcinoma risk associated with Helicobacter pylori may vary depending on the antigen used. CagA specific EnzymeLinked Immunoadsorbent Assay (ELISA) versus commercially available H.pylori ELISAs. Cancer.88 (7):1530-5.

Micu G, staniceanu F, Zurac S, Bastian A, Gramada E, Nichita L,et al., 2010.Carcinogenesis and infection with Helicobacter pylori.Rom $J$ Intern.48(4):299-306

Miehlke S, Hackelsberger A, Meining A, Arnim IV, Muller P, et al.. 1997. Histological diagnosis of Helicobacter pylori gastritis is predictive of a high risk gastric cancer carcinoma. Int J.Cancer. 73:837-9.

Nagini S.,2012. Carcinoma of the stomach: a review of epidemiology, pathogenesis, molecular genetics and chemoprevention. World $J$ Gastrointest Oncol. 15: 4(7): 156-69

Noda N, Wakasugi H. 2004. Cancer and Oxidative stress.J JMA, 124(11):1571-74

Parsonett J, Friedman G.D, Daniel M.S, Vandersteen D.P, Chang Y, Vogelman J.H et.al., 1991. Helicobacter pylori infection and the risk of gastric carcinoma.NEng JMed, 325:1127-31

Paz-Bouzal J.I. Garcia, Abad M.M, Muaozl E, Rincon M.R, Bullon A., 1991. Chronic gastritis associated with helicobacter pylori. Correlation between histological and bacteriogical.Histol Histopath.6:485-9

Semino-Mora C, Doi SQ, Marty A, Simko V, Caristedt I, Dubois A., 2003.Intracellular and interstitial expression of Helicobacter pylori virulence genes in gastric precancerous intestinal metaplasia and adenocarcinoma.J Inf Dis. 187 : 1165-77.

Suzuki H, Nishizawa T, Masaoka T, Mori M, Iwasaki E, Tsicimoto K, et al., 2005. Helicobacter pylori and gastric cancer. $J M A J, 48(10): 497-04$

Syaifudin M. 2008. Pengembangan teknik biologi molekuler untuk deteksi Helicobacter pylorI pada penderita dyspepsia.available from http://www.nhc.batan.go.id/syaifudin.php1

Tokudome S, Samsuria W.D, Soeripto, Triningsih F.X.E, Suzuki S, Hosono A,et al., 2005. Helicobacter pylori infection appears 
essential for stomach carcinogenesis : observations in Semarang, Indonesia.Cancer Sci, 96(12):873-75.

Valko M, Izakovic M, Mazur M, Rhodes CJ, Telser J., 2004. Role of oxygen radicals in DNA damage and cancer incidence.Mol cell Biochem,266:37-56

Yuan JP, Li T, Chen HB, Li ZH, Yang GZ,Hu BY, et al., 2004. Analysis of gene expression profile in gastric cancer cells stimulated with Helicobacter pylori isogenic strains. $J$ Med Microbiol, 53:965-74

Zhang C, Yamada N, Wu YL, Wen M, Matsuhisa T, Matsukura N., 2005. Helicobacter pylori infection, glandular atrophy and intestinal metaplasia in superficial gastritis, gastric erosion, erosive gastritis, gastric ulcer, and early gastric cancer. World J Gastroenterol, 11(6): 791-6. 